\title{
Online marketplace: student consumer strategies
}

\section{KEYWORDS}

online market;

online trade;

online buyers;

online consumption strategies;

consumer behavior in the online environment;

online shopping

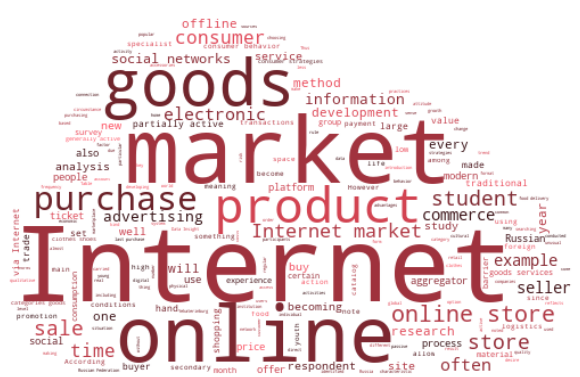

Word Cloud Generated by:

https://wordscloud.pythonanywhere.com/

\section{ABSTRACT}

Introduction. The Internet is becoming a part of everyday life; it is in this space that communication, purchases, and payment for various services are carried out. Young people are the most dynamic social group that has long mastered the Internet market with its advantages, namely, comparing prices, book products, and buy at discounts.

Materials and methods. The quantitative data collection method is used for studying young people's consumer strategies in the Internet market and understand the prevalence of online shopping practices. This task led to the application of the survey and the analysis of the data obtained. Comprehension of values and behavioral practices in consumer groups (generally active experts, partially active experts, passive experts) is based on a qualitative strategy in the form of semiformalized interviews.

Research results, their discussion. The factors of the popularity of the Internet market among students have been determined: activity on the Internet and social networks, attractive prices for goods, an expanded range of goods; it was found that such categories of goods as tickets, music, software, and food delivery are frequently purchased via the Internet; it was revealed that the frequency of online purchases varies from "once every six months" to "once every 1-3 months", while a purchase does not always accompany a visit to an online store. The survey showed that the most preferable for young people are such services, Internet catalogs, the possibility of placing a preliminary order, booking goods with subsequent self-pickup.

Conclusions. The study made it possible to establish a trend towards increasing online purchases among students in the Internet market as a consumer platform with new consumption practices.

Novgorodtseva, A. N., Tomyuk, O. N., Dyachkova, M. A., \& Piankova, M. P. (2020). Online marketplace: student consumer strategies. Economic consultant, 32 (4), 41-53. doi: 10.46224/ ecoc.2020.4.5 


\section{INTRODUCTION}

$\mathrm{O}$ the one hand, consumer behavior always reflects the specific historical conditions for the development of markets and the economy as a whole. On the other hand, consumer behavior reflects certain values and lifestyle standards of certain groups. The main consumer groups are usually identified based on socio-economic strata. However, the modern market is strengthening the segmentation by gender and age. Thus, the consumer practices of student youth are becoming the focus of attention of modern companies. It is student youth who are ready to experiment and learn new strategies and practices. Students are active in virtual reality, which daily fills life with new information presented on the Internet by text, digital, audio-video materials. For today's youth, access to the Internet space on Internet market platforms is seen as a manifestation of freedom of choice. The result of the active activity of Internet users is the emergence of new trends, fashion trends. So, the fashion for street style in clothes was set by young artists, designers, and photographers to popularize an active lifestyle on the Internet. The online marketplace is producing new consumption strategies, saving and responding to offers from the online marketplace. This circumstance determines the relevance of studying the Internet market as a market with new student consumer behavior strategies. According to experts, today, the Asia-Pacific region is the leader in online sales [3]. The global nature of trade can both catalyze the development of the Internet market and become a significant barrier; for example, it is difficult to regulate Internet transactions with the norms adopted in the territory of one country (in particular, goods allowed for sale, for example, drugs and methods of their delivery). At present, there is a process of unification of the norms and regulations of the global Internet trade based on common world principles.

\section{MATERIALS AND RESEARCH METHODS}

The transition to the Internet space does not reject the basic framework of analysis. It is customary in the sociological tradition to analyze the market as a social institution. Using this approach to understanding the structure of the market, one can comprehend the content of connections, define supra-individual formations, including a multi-level system (states, firms, rules, laws, and practices), and interaction between social groups. Within the framework of the economic and sociological approach, the market is defined as a system of regular mutually beneficial exchange of goods. Participants' actions are regulated (in addition to price policy) by their structural ties, institutional forms, and cultural constructions. Thus, social relations reproduced by market participants come to the fore. The collection of empirical material was carried out using survey methods and semi-formalized interviews. Questionnaire and online surveys were conducted in 2017. 
The object of the research was the student youth of the city of Yekaterinburg. The sample of the study consisted of 150 people selected based on a quota, with quotas being carried out according to the characteristics of "gender", "course of study", "full-time education", "residence in the city of Yekaterinburg". The "snowball" method was used as a selection method. The data array was processed using the Vortex program. Through a quantitative survey and analysis of the literature, four groups of consumer strategies were identified. Moreover, during the research's qualitative stage, the emphasis was placed on the most common types - "generally active" and "partially active". Nine semi-formalized interviews were conducted with students with different levels of involvement in Internet consumption (Table 1).

Table 1

Typology of consumer strategies

\begin{tabular}{|l|c|c|}
\hline \multirow{2}{*}{} & \multicolumn{2}{|c|}{ Representation in the study } \\
\cline { 2 - 3 } & Qualitative research & Qualitative research \\
\hline Specialists & $7,4 \%$ & 1 \\
\hline Generally active & $36 \%$ & 3 \\
\hline Partially active & $46,6 \%$ & 3 \\
\hline Passive & $10 \%$ & 2 \\
\hline
\end{tabular}

To check the study's conclusions' adequacy, we turned to the secondary data of Data Insight (2014-2020), analytical articles, and expert opinions, which are in the public domain.

\section{ANALYSIS OF THE LITERATURE}

Globalization and the world economy are inconceivable without internet commerce. Seetharaman A., Niranjan I., Saravanan A. S., Balaji D. A. believe that e-commerce is one of the most types of activities carried out via the Internet popularity among consumers of goods and services [4, p. 397-412]. The set of institutions that form the market is a set of certain rules developed common understandings and interpretations, a collective behavior system. Rules and regulations both restrict and stimulate the actions of market participants. Institutions eliminate the costs of choosing an option in an ordinary market situation, offering ready-made action schemes. They allow predicting other people's actions according to common sense and market participants' natural attitude [1]. In the study of Azar S., Khan S. N., Shavaid J., it is substantiated that the online market allows making trade transactions without any geographic restrictions [5, p. 133-144]. At the same time, Azar S., Khan S. N., Shavaid J. note that although online commerce has many advantages, buyers often show dissatisfaction with commercial transactions via the Internet. The main thing on which buyers' dissatisfaction with trade transactions via the Internet is that the goods cannot be tried on to see how it happens in traditional trade, in real stores. The research has shown that detailed acquaintance with a 
product on the Internet market positively affects the degree of customer satisfaction. Factors that positively impact the attitude to trade via the Internet are also the web site's design with detailed information about the product, methods of purchasing it, pricing, customer service, and logistics services. Azar S., Khan S. N., Shavaid J. note that the number of people making online purchases is rapidly increasing [5, p. 133-144]. In the work of Melissa G. Ocepek, the information behavior of consumers, the connection of the senses as sources of information with the choice of goods, in particular food products, has been investigated [6, p. 371-394]. The researcher notes that buyers rely on sight, taste, touch, smell [6, p. 371-394] in the process of searching and choosing products.

Consequently, in the Internet market, buyers search only for food products that they understand, which most often makes up their consumer basket. The study focuses on substantiating the sense organs, non-textual, verbal sources of information in a grocery shopper's behavioral strategy in grocery stores. Online shopping behavior is studied by El-Deeb S., Hamed S., with an emphasis on the motives and perceived risks when making online purchases [7, p. 31-55]. It has been established that the factors of success in electronic retail are utilitarian and hedonistic motives, which, at the same time, serve as the basis for the perceived risks of online shopping [7, p. 31-55]. According to expert estimates, in the next 3-5 years, the greatest growth potential for online commerce will be characteristic of large regional centers, cities with a population of over 1 million people. According to the Data Insight agency, the average growth in online commerce in the period from 2011 to 2019 was 28\% (from 235 billion rubles to 1.72 trillion, including VAT) [8]. In 2020, regions in Russia account for up to $80 \%$ of Internet buyers and about $65 \%$ of the Internet commerce market [9]. According to the rating also compiled by the Data Insight agency, in 2017, the largest online stores (TOP-15) were online stores operating in five key areas: hypermarkets (department stores), electronics and appliances, clothing, footwear, and accessories, goods for home and renovation and food. Besides, online sales platforms and divisions of large offline stores are becoming the leaders of the rating.

It should be noted that Internet retailers are also strengthening their physical presence by developing networks of both points of issue and full-format offline stores [10]. The dynamics of the development of the Internet market is explained by the low barrier to entry into the Internet market (up to a complete lack of investment), low costs, which allows offering consumers goods at more affordable prices, while the formats of discount stores and sales stores are becoming popular especially in conditions decrease in real incomes of the population. Traditional sellers have contributed to the development of the market by actively developing less expensive electronic sales methods.

The e-commerce market will continue to develop. This process is because users of online stores can quickly compare sellers of interest (for example, through aggregators/ marketplaces). This process serves as a catalyst for regular promotions by both electronic (online) and traditional (offline) merchants. Traditional sellers are also, following the global trend, developing their electronic divisions (for example, the French hypermarket "Auchan") 
to maintain competitiveness in the digital reality. At the same time, new market entities are continually appearing, mainly small and medium-sized ones, since the barriers to entering the market are quite low. The Internet is gradually becoming a key operating environment, and merchants who expect to reach the largest number of buyers will not afford to abandon e-commerce. It should be noted that the modern realities of 2020 and the pandemic have made a change in the development of online commerce, acting as a growth factor.

\section{CHANGE IN FORECAST DUE TO THE PANDEMIC}

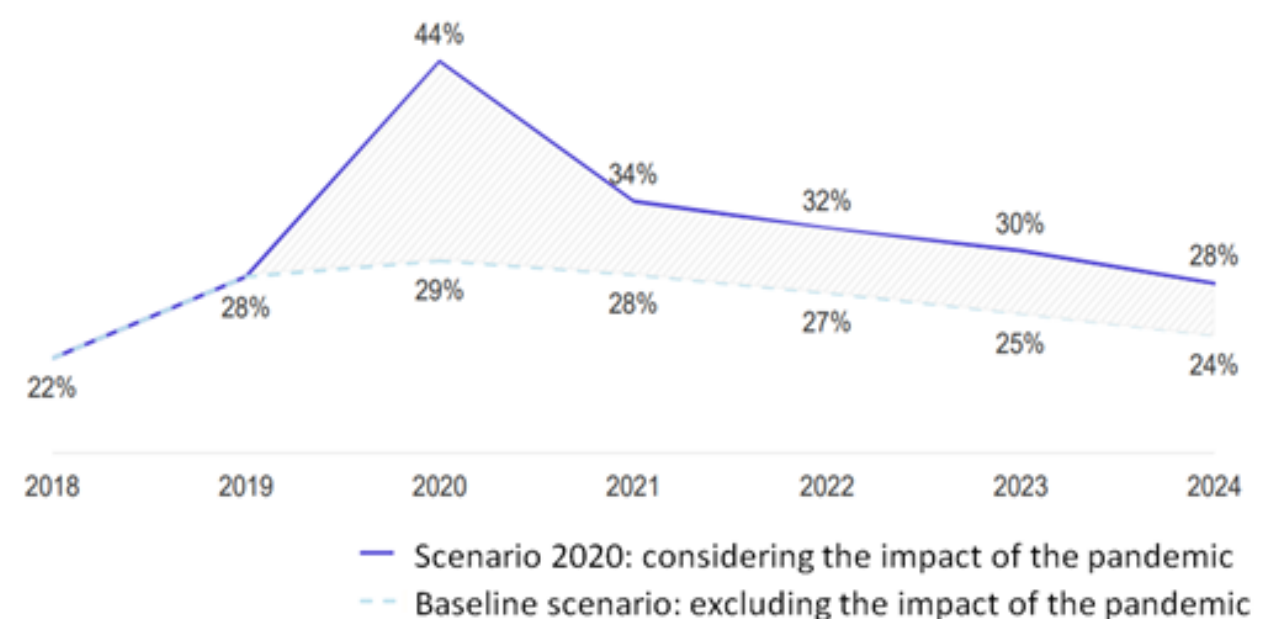

Figure 1 Forecast of the development of the Internet market from Data Insight [8]

In 2020, J. Scanlon conducted a study on the impact of COVID-19 threats on consumers' portfolio of educational services in the field of higher and secondary vocational education [11]. The conclusion is made about the increased demand for educational services provided remotely using distance technologies.

R. Misra, R. Mahajan, N. Singh believe that the electronic trading platform as an advanced technological infrastructure provides prospects and additional benefits, for example, for sellers of clothing and home decor [12, p. 1-41]. The study identified sellers' problems and expectations from the introduction of the electronic market, showing the advantages of electronic marketplaces for sellers [12, p. 1-41].

The Internet is a channel of direct influence on today's youth's value orientations, which are characterized by consumption attitudes, which can not affect the amount of direct or indirect advertising on the Internet. In this context, the Internet, particularly various kinds of advertising information within the Internet, "becomes a kind of demonstration material, a world of ideas and values, since it speaks not only about goods, but exposes typical situations of social interaction" [13]. Thus, according to analysts from the Public Opinion Fund, online advertising and television positions have become equal; during the current year, the Internet will bypass television in terms of the amount of budget spending on advertising [14]. The same position in the research of the study of the audience "Google". For example, online videos are becoming for the modern generation of "visuals" not so much entertainment as 
quick answers to questions: young people use YouTube to find relevant answers that arise in various situations. "Considering this in their advertising campaigns, advertisers can come to the rescue at key moments where their audience is looking for information" [15]. It is worth noting that it is in the space of virtual social networks that advertising begins to live a new life, and advertising blocks separating information are replaced by personalized advertising-integration tied to a certain Internet authority's personality.

We agree that the practices inherent in online commerce indicate that this is a serious business in which a wide range of consumers is involved [16, p. 214-232]. The Internet market sets the main trends in the development of consumer requests, actively developing advertising while creating the necessary conditions for the most convenient and comfortable transactions of any kind, thanks to which the Internet is gaining more and more recognition among students.

\section{RESEARCH RESULTS AND DISCUSSION}

As a set of cultural constructions, the market is immersed in a social context. It appears as a set of knowledge, skills, skills, established economic norms, values, and symbols, used meanings and meanings, combining cognitive, value, and symbolic aspects. All this is reflected in the positioning of a product in the modern market: any product carries a symbolic meaning beyond the physical properties of the offered product, its direct utility. It absorbs a set of images and meanings that the consumer recognizes using cultural codes known to him. Thus, in the production and sale of products and services, the market becomes a means of production and dissemination of norms and values, the approval of status hierarchies, an arena of symbolic struggle for the interpretation of meanings [2].

In all the fullness of these connections, the market space becomes a kind of conductor that reproduces processes that cover all spheres of society. In this regard, the Internet is becoming the most relevant and convenient form of organizing market space in modern society. The Internet market (Internet market) is a collection of all operations related to trading on the Internet: retail and wholesale purchase/sale of goods and services through an electronic network (online stores and other resources). The main formats for organizing Internet sites in the Russian segment, focused on the work of companies with individuals, are [17]:

- aggregator sites (specialized intermediary portals that automatically collect and process information from different suppliers in certain product areas);

- online stores (websites that post information about goods/services available for ordering and payment via the Internet);

- catalogs (showcases) in social networks (an online catalog of goods/services placed in an account or group in social networks to organize and promote sales of goods/services with the possibility of direct purchase and payment. Currently, social networks offer various tools for organizing e-business). 
The analysis of the sources made it possible to highlight the features that characterize Internet commerce development in Russia:

- poor development of logistics over a large territory of the country. Despite the success of the "Russian Post" in promptly arranging delivery for online stores, logistics remains a weak link. In this regard, many Internet sellers are planning to create logistics channels based on their offline representations autonomously. However, only large chains can afford this method due to the high costs on the seller's part. For medium and small Internet companies, the way out can be an Internet aggregator's activity and the activities of courier services;

- pressure from foreign and shadow competitors on bona fide Russian Internet sellers. Foreign online stores will increase their market share in the Russian Federation since they will offer cheaper and, at the same time, high-quality goods due to tax savings. It is important to note that foreign chains are aware of the Russian Federation's potential; therefore, they are introducing a Russified interface since it is the language barrier that is the main barrier to online purchases in foreign online stores;

- low level of trust in online purchases. Even though the rather high penetration of the Internet in the Russian Federation, the growth of the level of technological literacy, financial culture (use of non-cash means of payment), the central problem of Russian Internet commerce is becoming distrust of online stores, as well as of the quality of the products they offer. This circumstance is because the risk of acquiring illegal goods in the Russian Federation is quite high. In this regard, in the near future, traditional (offline) points of sale (shopping centers, hypermarkets near the house) for certain categories of goods will continue to enjoy great consumer confidence.

According to experts, the dynamics of the Russian Internet market's development will be positive despite the presence of the above barriers. However, improving legislation, leveling competitive advantages between domestic and foreign players, and establishing logistics will give the market a new impetus in difficult macroeconomic conditions [17]. Summing up, it can be noted that the Internet is becoming an indispensable platform for trade and a portal for the formation of a multifaceted market for goods and services covering all spheres of people's life.

Let us take a closer look at the Russian Internet market. In our research, the differentiation of Internet sites was carried out, and the specificity of each of them was revealed:

- online stores: universal platforms, large platforms with a wide range of goods, including almost all categories of goods - "Aliexpress", "eBay", "JD", "Ozon" and other online stores;

- online mono-brand stores as brand stores representing one group of goods - most often, clothes/shoes/accessories, furniture, etc. - "Asos", "Lamoda", "Wildberries", Labyrinth and other online mono-brand stores;

- online stores with large offline platforms are another service to the existing sizeable retail network - MVideo, Ikea, Chitai-Gorod, DNS, Golden Apple, and other online stores;

- online stores of secondary sale, that is, intermediary services for the sale of often used 
goods from individuals to each other - "Avito", "Joom", "Yula" and other online stores of secondary sale;

- aggregator sites that allow comparing prices and offers of all sellers on the Internet "Aviasales", "Yandex-market" and other aggregator sites;

- Internet catalogs in social networks, business accounts with the sale of goods on social networks "Instagram", "VKontakte", "YouTube" and other social networks often perform only the function of a catalog and promotion of goods with the provided tools for purchasing and, as a rule, with a separate website for the online store.

It should be noted that sellers often combine store formats to achieve the best results. For example, mono-brand online stores often have social media accounts with the ability to order and purchase through them; actions with secondary sale elements are often organized on social networks, aggregators have been introduced into online stores with offline sites to prove the most profitable offers on the market.

During the analysis, the most popular products sold on the Russian Internet market and the frequency of their purchases by the youth of Yekaterinburg were identified. For the subsequent analysis, it is important to highlight the analytical model of consumer strategies of youth. Analysis of the results of quantitative and qualitative research methods allowed identifying the following typology of consumers (consumer strategies):

- specialists working in the field of online market or marketing;

- generally active, with experience of regular purchases (more than three categories of goods);

- partially active, with experience of irregular purchases (less than three categories of goods);

- $\quad$ passive, having experience with a single purchase (1-2 goods).

Table 2 illustrates consumer responses combined with different consumer strategies.

Table 2

Frequency of purchase of product categories

\begin{tabular}{|c|c|c|c|c|c|c|}
\hline \multirow[b]{2}{*}{ Product categories } & \multicolumn{6}{|c|}{ Purchase frequency, \% } \\
\hline & $\begin{array}{c}1 \text { time in a } \\
\text { month and more } \\
\text { often; } \\
>12 \text { times a year }\end{array}$ & $\begin{array}{c}1 \text { time in } \\
2-3 \text { months; } \\
\text { 4-6 times a year }\end{array}$ & $\begin{array}{l}2-3 \\
\text { times a } \\
\text { year }\end{array}$ & $\begin{array}{l}\text { once a } \\
\text { year or } \\
\text { less }\end{array}$ & 1 time & never \\
\hline Food (delivery) & 30,7 & 26,0 & 15,3 & 6,7 & 15,3 & 2,7 \\
\hline $\begin{array}{l}\text { Mobile / digital devices, } \\
\text { accessories }\end{array}$ & 2,0 & 12,0 & 18,0 & 26,0 & 24,7 & 14,0 \\
\hline Hobby and sports goods & 4,0 & 8,7 & 17,3 & 23,3 & 12,0 & 31,3 \\
\hline Clothes and footwear & 8,7 & 15,3 & 27,3 & 18,7 & 8,7 & 18,0 \\
\hline $\begin{array}{l}\text { Image accessories (jewelry, } \\
\text { watches) }\end{array}$ & 2,7 & 4,0 & 12,0 & 16,7 & 18,0 & 43,3 \\
\hline $\begin{array}{l}\text { Electronic purchases (tickets, } \\
\text { music, software, games) }\end{array}$ & 15,3 & 27,3 & 18,0 & 14,0 & 8,7 & 13,3 \\
\hline
\end{tabular}




\begin{tabular}{|l|c|c|c|c|c|c|}
\hline $\begin{array}{l}\text { Health and beauty (cosmetics, } \\
\text { perfumery, medicines) }\end{array}$ & 3,3 & 11,3 & 8,7 & 10,0 & 10,7 & 52,7 \\
\hline $\begin{array}{l}\text { Collectible goods (comics, } \\
\text { records }\end{array}$ & 2,0 & 3,3 & 2,7 & 9,3 & 8,0 & 71,3 \\
\hline Stationery and books & 4,7 & 12,7 & 14,0 & 13,3 & 6,0 & 46,0 \\
\hline Furniture & 0,7 & 4,0 & 6,0 & 7,3 & 78,7 & 0,0 \\
\hline Household appliances & 2,0 & 4,7 & 8,7 & 13,3 & 11,3 & 56,7 \\
\hline Other & 4,0 & 4,7 & 7,3 & 4,7 & 7,3 & 68,7 \\
\hline
\end{tabular}

The most preferred categories of goods, often (once every 2-3 months or more) purchased by students on the Internet, are electronic purchases - tickets, music, software (42\% in total), food delivery (57\% in total). Despite this, food delivery is not a specific category of goods for a consumer-student: almost every second respondent considers it more expedient to buy food in an offline store (45\%), and every fourth student (27\%) decides to buy food from online service depending on promotions and sales. This data is due primarily to the difficulties associated with the long waiting time for the order: "... even online payment, and then they say that you have to wait 2.5 hours, and you are hungry ..." ( $f$, partially active).

Electronic ticket purchases, in turn, are also becoming an integral part of the consumer behavior of a modern student: "I bought tickets from Russian Railways so as not to stand in queues at train stations, it was very convenient" (m, partially active), "I buy tickets every week" ( $m$, generally active). On the other hand, the purchase of electronic tickets for leisure activities routinizes the very process of consumption "for a special occasion": "if there is a ticket for my favorite band, which I have dreamed of going to all my life ... then I will get worn out and buy a paper ticket. Well, in order to feel the consumer "experience" as much as possible" (m, specialist). A similar situation with purchases of unusual and gift goods on the Internet: on the one hand, PR and SMM technologies, as well as the introduction of their own, often commercial blog directly by the seller himself (for example, in the case of the category of "hand-made" goods) facilitates the path from the seller to the buyer: "It is interesting to buy some designer things: there are many shops run by an artist/sculptor who make a single copy, without an Internet blog this thing can never be found" (well, passive). "I was buying ... a unique piece of jewelry, which is made by one master somewhere incomprehensible. Well, that is, I don't even know where he lives, well, somewhere in Russia ... it doesn't matter where he lives, and I was able to acquire this unique item via the Internet, which is, in general, huge plus" (m, specialist). Another opinion: "Gifts: this year online stores generally rescued me because I bought almost all the gifts through them ... something from entertainment, roughly speaking. Or decor" ( $m$, generally active). However, on the other hand, the Internet deprives the buyer of the very process of searching for an unusual product/store: "But if you use it to buy something unusual, you want, as it were, not to use it, but to use your real eyes, ears, hands and so on. Well, this is because you want to feel a special case somehow. Therefore, if I want to buy something cool, I'd rather do it myself" (m, specialist).

Along with electronic goods and food delivery, the category "clothes and shoes" is also popular among online purchases: the majority of students ( $72 \%$ in total) buy clothes and shoes 
2-3 times a year and more often. When choosing shoes or clothes, respondents are also guided by promotions and sales (41\%), but almost every 2 nd student considers the traditional way of buying clothes on offline trading platforms to be the most appropriate. Example: "Well, but something that goes beyond the boundaries of everyday life, something unusual, for example, a skirt that you have never worn before, I would buy it in a physical store so that you can try on" (well, partially active). The high relevance of purchases, for example, clothes and shoes on the Internet, is confirmed by the popularity among students of Internet sites selling this particular category of goods. Sites and mobile applications "Lamoda", "Asos", "Wildberries", "H\&M" are mentioned by every second student (56\%). The last purchase statistics confirm this: $17 \%$ of the respondents purchased clothes, $8 \%$ - shoes. It should be clarified that the data of the last purchase is also due to the change in the wardrobe of the respondents in connection with the change of season.
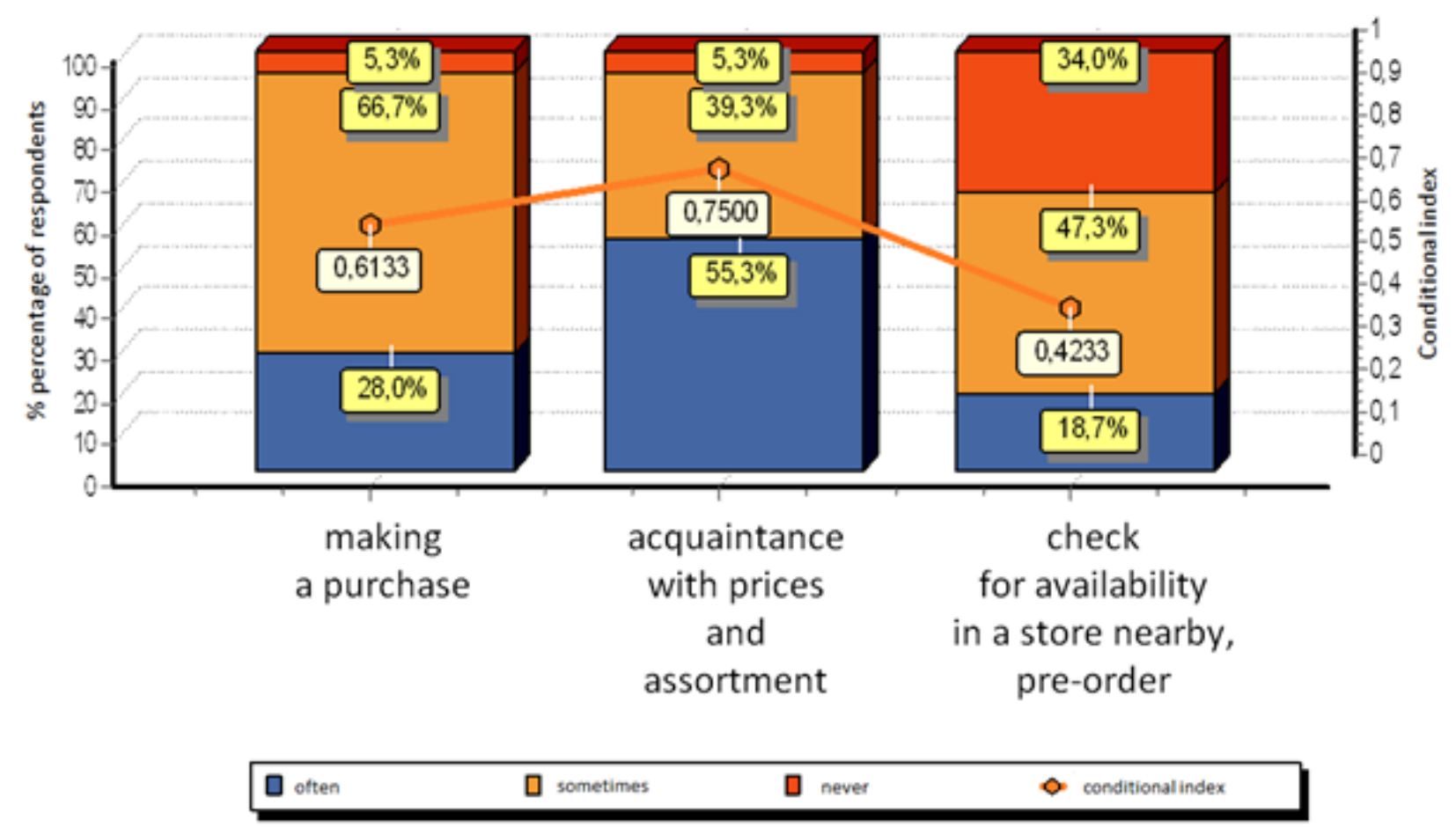

Figure 2 Purpose of visiting the online store

The survey materials showed that students with Internet consumption experience make online purchases, mainly, once every six months (38.7\%), once every $1-3$ months (29.3\%). However, a visit to an online store is not always accompanied by a purchase. The most preferable are the following functions:

- the use of online catalogs posted on the store's website in order to get acquainted with prices and assortment (55\% of respondents do this regularly, and 39\% - sometimes);

- checking the store's availability, pre-ordering a product, or booking it with subsequent pick-up (19\% of respondents do it regularly, 47\% sometimes).

"I have a phone from an online store, it costs 3 thousand less than in a physical store. It was selected through aggregators such as Yandex-Market, which monitor where it is and 
what the price is" ( $f$, partially active). The last purchase of every 2 nd respondent (50\%) dates from the month of the survey; the rest of the survey participants made their last purchases during the year, while only $1.3 \%$ of respondents bought the product more than one year ago. This circumstance testifies to the current shopping experience and the increasing frequency of purchases via the Internet.

Note that many features characterize the modern young consumer who actively uses the Internet:

- requirements for expanding the number of options, since the ability to choose between several options carries value for the "network" generation that grew up in conditions of freedom and interactivity;

- the desire to customize, adjust the products for yourself, express individuality with its help (both externally, by changing materials and colors, and internally, by changing the settings and options of the product);

- quick change of preferences: both a positive phenomenon for manufacturers of goods (attracting new customers) and negative phenomenon (low loyalty to products);

- the desire to try out the products, make sure of its quality (the desire to get a trial version, for example, in multimedia products - music, programs, games);

- a shift from the product's external characteristics to its functionality, the conceptual balance between design and product characteristics [18].

\section{CONCLUSION}

The adherence to online shopping is determined by several factors: activity on the Internet and social networks, relatively low prices for goods on the Internet market, an expanded range of goods (not only the local market). The vast majority of respondents use social networks every waking hour, and more often: 38\% - hourly, 34\% - more often than one time in half an hour. Social media is a powerful lever for the operation and distribution of online marketing, generating demand, and providing supply. A large flow of advertising accompanies this process on the Internet: $90 \%$ of that surveyed claim to have encountered contextual advertising on social networks.

Students' commitment to online shopping is a complex social phenomenon that reflects the demands of the times. This circumstance is why $94 \%$ of users expect to shop online again. Students' commitment to shopping in online markets is determined by their desire to receive great offers, participate in promotions and sales, quickly find the best product in terms of price and quality through Internet aggregators, which, in aggregate, can significantly save on purchases. It is crucial to gain access to a broad market for goods outside the student's home. This access allows purchasing goods that are not among the students of the immediate environment and thanks to which people can look more advantageous. 
Today's youth's consumer behavior demonstrates a tendency to increasingly redirect the flow of purchases from traditional forms to purchases in the Internet market. Young people are characterized by analysis of prices and offers, searching for information about a product, checking availability, booking/making a preliminary product, fast online payment, and other Internet activities. A combined method of consumption comes to the fore, combining the market analysis for goods through Internet sources and receiving goods directly on the offline market, which significantly minimizes the risks associated with Internet intermediaries.

\section{REFERENCES}

1. Garfinkel, G. (2007). Research on ethnomethodology. Saint-Petersburg, Peter Publ., 267 (in Russian).

2. Slater, D. (2007). Taking the market away from economists // Radaev, V. V., Dobryakova, M. S. Analysis of markets in modern economic sociology. Moscow, Ed. House of the Higher School of Economics, 387 (in Russian).

3. Popova, E. A., Nikitin, D. M., Teterkin, N. V., Gevorgyan, K. Kh. (2018). Analysis of the online trading market in Russia. Economy. Management. Person, 4, 1-6 [Electronic resource]. Access mode: https://s.siteapi.org/f48d818f18b0289/docs/9u90cfcolekgc480 08scw0sss40wg4 (date accessed: 15.08.2020) (in Russian).

4. Seetharaman, A., Niranjan, I., Saravanan, A. S., Balaji, D. (2017). A Study of the Moderate Growth of Online Retailing (Ecommerce) In the UAE. The Journal of Developing Areas. Tennessee State University College of Business, 51, 4, 397-412.

5. Azar, S., Khan, S. N., Shavaid, J. (2015). Familiarity with Online retailing. The Journal of Developing Areas Tennessee State University College of Business, 49, 6, 133-144.

6. Melissa, G. (2018). Ocepek. Sensible Shopping: A Sensory Exploration of the Information Environment of the Grocery Store. Library Trends Johns Hopkins University Press, 66, 3, 371-394.

7. El-Deeb, S., Hamed, S. (2019). Refining Scales on Risks and Motives of Online Buying. e-Service Journal Indiana University Press, 11, 1, 31-55.

8. Electronic commerce 2020-2024, Data Insight forecast (14 July 2020) // Data Insight [Electronic resource]. Access mode: https://datainsight.ru/DI_eCommerce2020_2024 (date accessed: 15.08.2020) (in Russian).

9. Internet commerce in Russia 2014. Final report. [Electronic resource]. Access mode: http://www.datainsight.ru/ecommerce2014 (date accessed: 15.08.2020) (in Russian).

10. Rating of the TOP-100 largest online stores in Russia 2017. [Electronic resource]. Access mode: http://datainsight.ru/top100 (date accessed: 15.08.2020) (in Russian).

11.Scanlon, J. (2020). What It Means to Teach Consumer Culture Remotely Through a Pandemic. Advertising \& Society Quarterly. Advertising Educational Foundation, 21, 2. 12. Misra, R., Mahajan, R., Singh, N. (2020). Understanding Factors Affecting Receptivity Towards Adopting Electronic Marketplace: A Merchant Perspective. e-Service Journal Indiana University Press, 12, 1, 1-41.

13. Sedykh, I. A. Market of Internet trade in the Russian Federation. [Electronic resource]. Access mode: https://dcenter.hse.ru/data/2017/03/10/1169536647.pdf (date accessed: 
05/01/2020) (in Russian).

14. Chukreev, P. A., Togoshieva, A. V. (2011). Features of socialization of youth under the influence of advertising. Bulletin of the Buryat State University, 6, 119 (in Russian).

15. Research FOM: The volume of the domestic advertising market showed growth in 2017 [Electronic resource]. Access mode: http://fom.ru/blogs/14018 (date of access: 30.04.2020) (in Russian).

16. Zeeuw, D. de, Tuters, M. The Internet is Serious Business: On the Deep Vernacular Web and Its Discontents. Cultural Politics. Duke University Press, 16, 2, 214-232.

17. A new generation of Internet users: a study of the online habits and behavior of Russian youth. Google Audience Research: Teens and Young People. Ipsos Connect Research. 2017. [Electronic resource]. Access mode: https://www.thinkwithgoogle.com/intl/ruru/insights-trends/user-insights/novoe-pokolenie-internet-polzovatelei-issledovanieprivychek-i-povedeniia-rossiiskoi-molodezhi-onlain/14018 (date of access: 30.04.2020) (in Russian).

18. Tapscott, D. Growing up Digital: The Rise of the Net Generation. New York: McGraw Hill. 1998 [Electronic resource]. Access mode: http:// library.hse.ru/e-resources/eresources.html (date of access: 25.05.2020).

\section{INFORMATION ABOUT THE AUTHORS}

1. Anastasia N. Novgorodtseva (Russia, Ekaterinburg) - Associate Professor, PhD of Sociological Sciences, Associate Professor Department of Applied Sociology Department of Political Science and Sociology, Ural Humanitarian Institute. Ural Federal University named after the first President of Russia B.N. Yeltsin. E-mail: a.n.novgorodtseva@urfu.ru. Scopus ID: 57215904946

2. Olga N. Tomyuk (Russia, Ekaterinburg) - Senior Lecturer, Department of Theory of State and Law, Ural State Law University. E-mail: helgago@yandex.ru. Scopus ID: 57211983935

3. Margarita A. Dyachkova (Russia, Ekaterinburg) - Associate Professor, PhD in Pedagogical Sciences, Associate Professor of the Department of Art Education. Ural State Pedagogical University. E-mail: dyachkova.margarita@yandex.ru. Scopus ID: 57211982998

4. Maria P. Piankova (Russia, Ekaterinburg) - Magister of Department of Applied Sociology Department of Political Science and Sociology, Ural Humanitarian Institute. Ural Federal University named after the first President of Russia B.N. Yeltsin. E-mail: hi.mark@inbox.ru

\section{(c) ()}

Available: https://statecounsellor.wordpress.com/2020/12/01/novgorodtseva-2/

Received: Sep 14, 2020 I Accepted: Oct 20, 2020 I Published: Dec 1, 2020

Editor: Yuri I. Treshchevsky, Professor, Doctor of Economics. Voronezh State Univercity, RUSSIA

Copyright: (C) 2020 Novgorodtseva, A. etc. This is an open access article distributed under the terms of the Creative Commons Attribution License, which permits unrestricted use, distribution, and reproduction in any medium, provided the original author and source are credited.

Competing interests: The authors have declared that no competing interests exist. 